\title{
Effect of levofloxacin on neutrophilic airway inflammation in stable COPD: a randomized, double-blind, placebo-controlled trial
}

This article was published in the following Dove Press journal:

International Journal of COPD

7 February 2014

Number of times this article has been viewed

\author{
Roshan Siva' \\ Mona Bafadhel ${ }^{2}$ \\ William Monteiro ${ }^{3}$ \\ Christopher E Brightling ${ }^{3}$ \\ Ian D Pavord ${ }^{2}$ \\ 'Department of Respiratory Medicine, \\ Croydon University Hospital, \\ Croydon Health Services NHS Trust, \\ London, ${ }^{2}$ Department of Respiratory \\ Medicine, Nuffield Department of \\ Clinical Medicine, University of \\ Oxford, Old Road Campus, Oxford, \\ ${ }^{3}$ Institute for Lung Health, NIHR \\ Respiratory Biomedical Research \\ Unit, Department of Infection, \\ Immunity and Inflammation, University \\ of Leicester, Leicester, UK
}

Correspondence: lan D Pavord Department of Respiratory Medicine, NDM Research Building, Nuffield Department of Medicine, University of Oxford, Old Road Campus, Oxford OX3 7FZ, UK

Tel +44 I865 612897

Email ian.pavord@ndm.ox.ac.uk
Rationale: Airway inflammation persists after smoking cessation in established chronic obstructive pulmonary disease (COPD), suggesting that other factors drive the airway inflammatory response.

Objectives: We tested the hypothesis that high levels of bacterial colonization are associated with increased levels of neutrophilic airway inflammation in stable COPD by examining the crosssectional relationship between these measurements and by conducting a randomized, double-blind, placebo-controlled study of the effect of levofloxacin in patients with stable COPD.

Methods: Patients were randomized to receive either levofloxacin $500 \mathrm{mg}$ daily or placebo for 7 days and underwent sputum induction for a differential cell count and quantitative bacterial analysis at baseline and at days 7, 14, and 28.

Results: Sputum percentage neutrophil count correlated with airway bacterial load at baseline ( $r=0.56 ; P=0.003$ ). Levofloxacin reduced bacterial load compared with placebo by 4.9 -fold (95\% confidence interval, $1.4-25.7 ; P=0.02)$ at day 7 but had no effect at any point on any marker of neutrophilic airway inflammation. In patients with a baseline bacterial load of more than $10^{6} \mathrm{cfu} / \mathrm{mL}$, levofloxacin treatment was associated with a $26.5 \%$ (95\% confidence interval, $1.8 \%-51.3 \% ; P=0.04$ ) greater reduction in the percentage neutrophil count compared with placebo at day 7 . Change in percentage neutrophil count correlated significantly with baseline airway bacterial load and change in airway bacterial load.

Conclusion: In stable COPD, levofloxacin treatment causes a short-term reduction in bacterial load. This is associated with a reduction in neutrophilic airway inflammation in patients with high bacterial loads. Further studies are required to investigate whether this effect is clinically advantageous.

Keywords: bacteria, antibiotics, sputum

\section{Introduction}

Chronic obstructive pulmonary disease (COPD) is a slowly progressive chronic inflammatory disease, affecting mainly the airways, that is characterized by an accelerated decline in lung function. ${ }^{1}$ The main etiological agent associated with developing COPD is cigarette smoke, and smoking cessation has been shown to slow this accelerated decline in lung function. ${ }^{2}$ However, the rate of decline of lung function is variable among patients, and other sources of local $^{3-5}$ and systemic ${ }^{3,6}$ inflammation may contribute. In keeping with this view, airway inflammation has been shown to persist after smoking cessation in patients with established COPD. ${ }^{7,8}$

Neutrophilic airway inflammation has been shown to be associated with forced expiratory volume in 1 second $\left(\mathrm{FEV}_{1}\right)$ in cross-sectional analysis ${ }^{5}$ and, longitudinally, 
with decline in $\mathrm{FEV}_{1}{ }^{7}$, suggesting a role in the genesis of the small airway inflammation and fibrosis that leads to the progressive airflow obstruction seen in COPD. ${ }^{9}$ One potentially modifiable cause of neutrophilic airway inflammation is bacterial infection of the airway. The presence of potentially pathogenic microorganisms (PPMs) has been associated with higher levels of markers of neutrophilic airway inflammation during stable disease ${ }^{10}$ and at exacerbation. ${ }^{1-13}$ Moreover, uncontrolled studies have shown that reduction of bacterial load with antibiotic therapy is associated with resolution of neutrophilic airway inflammation in patients studied during an exacerbation ${ }^{14}$ with elevated total neutrophils in the presence of a PPM. ${ }^{15,16}$ Less is known about the relationship between bacterial colonization of the airway and neutrophilic airway inflammation in stable COPD. We have tested the hypothesis that high levels of bacterial colonization are causally associated with increased levels of neutrophilic airway inflammation in stable COPD by examining the cross-sectional relationship between these measurements and by conducting a randomized, doubleblind, placebo-controlled study of the effect of a 1 week course of levofloxacin on bacterial load and markers of neutrophilic airway inflammation in patients with stablestate COPD.

\section{Methods}

\section{Participants}

Participants with a physician diagnosis of COPD were recruited from Glenfield Hospital, Leicester, UK, between January 2003 and January 2004. All patients had fixed airway obstruction, with an $\mathrm{FEV}_{1} / \mathrm{FVC}$ ratio of $<0.7$ and an $\mathrm{FEV}_{1} \%$ predicted of $<80 \%$. The exclusion criteria were as follows: patients younger than 45 years; a clinical history of asthma or acute wheeze, breathlessness, or deterioration associated with allergens; or clinically important comorbidity such as heart failure, bronchiectasis, or lung cancer. Any evidence of airway reversibility following 400 micrograms of inhaled Salbutamol $(>15 \%$ or $>200 \mathrm{~mL}$ ) was also an exclusion criterion. Patients receiving regular antibiotic therapy, elevated immunoglobulin E levels ( $>500 \mathrm{U} / \mathrm{L})$, and PiZZ homozygosis for alpha-1 antitrypsin were also excluded. At enrollment, patients were 6 weeks free of an exacerbation. The study was approved by the Leicestershire and Rutland research ethics committee, and all subjects gave written informed consent. The clinical trial was not registered, as it was carried out before the mandatory requirements for registration of clinical trials.

\section{Measurements}

The following baseline characteristics were recorded: age, sex, body mass index, serum immunoglobulin E, alpha-1-antitrypsin level, smoking history, and comorbid history. All patients underwent a chest X-ray and full pulmonary function testing. Spirometry was always carried out in the morning and performed by taking the best of three readings, using Vitalograph ${ }^{\circledR}$ (Lenexa, KS, USA), before and 15 minutes after inhalation of salbutamol $400 \mu \mathrm{g}$ via a large-volume spacer device. Gas transfer and total lung volumes were measured using the single-breath-hold carbon monoxide technique and helium dilution technique, respectively. At each visit, patients underwent spirometry, sputum induction according to a standard protocol, ${ }^{17,18}$ diary card review, and assessment of symptoms using visual analog scales on which patients marked 3 lines, each measuring 100 $\mathrm{mm}$, which represented the symptoms of breathlessness, cough, and sputum production. ${ }^{19}$ Sputum was processed according to a standard protocol ${ }^{18}$ and analyzed for differential cell count by counting more than 400 nonsquamous cells on a Romanowski (0.5g Eosin, 1.5g Azure-B-thiocyanate, 10nM HEPES buffer pH7.2, dimethyl sulfoxide) stained cytospin. A quantitative bacterial count was performed by using homogenized sputum to create a dilutional series, which was then pipetted onto media plates and incubated for 24 hours. ${ }^{20}$ Bacterial colonies were identified and counted to calculate airway bacterial load, expressed as colony forming units $(\mathrm{CFU}) / \mathrm{mL}$ sputum. ${ }^{21} \mathrm{~A}$ potential PPM was defined as the presence of Haemophilus influenzae, Streptococcus pneumoniae, Moraxella catarrhalis, Staphylococcus aureus, or Pseudomonas species on routine sputum culture. ${ }^{20}$ Bacterial load higher than $\times 10^{6} \mathrm{cfu} / \mathrm{mL}$ was chosen a priori for subgroup analysis, as this level has been shown to be associated with increased neutrophilic airway inflammation. ${ }^{22}$ Sputum supernatants were frozen at $-80^{\circ} \mathrm{C}$ for measurement of interleukin-8 (IL-8) concentrations by enzymelinked immunosorbent assay, using a commercially available kit (R\&D Systems Europe, Abingdon, UK). The limit of detection of IL- 8 was $1.5 \mu \mathrm{g}$, and the between-assay and within-assay variability was between $5 \%$ and $10 \%$.

\section{Protocol}

At the baseline visit, patients were randomized to receive either a 7-day course of levofloxacin $500 \mathrm{mg}$ once daily or matched placebo in a randomized, double-blind control trial. The randomization process was carried out by Royal Hallamshire Hospital, which supplied the medication. The patients were followed up in the morning, at least 2 hours after taking their study medication, on days 7, 14, and 28, and measurements were repeated as stated earlier. Patients were asked to 
complete symptom diary score cards from the baseline visit to day 28. The study consort diagram is shown in Figure 1.

\section{Analysis}

The primary endpoints were change in sputum percentage neutrophil count, change in sputum IL-8 concentration, and the relationship between airway bacterial load and sputum percentage neutrophil count. Secondary endpoints were change in sputum total neutrophil count, symptoms, and postbronchodilator $\mathrm{FEV}_{1}$. The demographics of the two groups were compared using simple descriptive statistics. Changes in percentage neutrophil count, total neutrophil count, bacterial load, and IL-8 between each group were compared using unpaired Student's $t$-tests. The relationship between change in percentage neutrophil count and baseline bacterial load, as well as change in percentage neutrophil count and change in bacterial load, were analyzed using Spearman's rank correlation. The study was powered to have a greater than $80 \%$ chance of detecting a $20 \%$ difference in the percentage neutrophil count or a 2 -fold difference in IL-8 with levofloxacin compared with placebo at the $5 \%$ significance level. All data were analyzed with SPSS for Windows (version 16.0; IBM Corporation, Armonk, NY, USA). All data were analyzed with intention to treat; missing data were assigned using measurements extrapolated from the last available visit.

\section{Results}

There were 27 patients randomized to receive levofloxacin $(n=14)$ or placebo $(n=13)$. Subjects were well matched at baseline (Table 1). Two patients in the levofloxacin group withdrew from the study before day 7 because of Achilles tendonitis, confirmed on ultrasound scanning. At baseline, 6 patients had a PPM detected, and there was a correlation between the sputum percentage neutrophil count and log airway bacterial load ( $r=0.56 ; P=0.003$; Figure 2$)$. At day 7 , the bacterial count increased from $1.1 \times 10^{6} \mathrm{cfu} / \mathrm{mL}$ to $1.5 \times 10^{6} \mathrm{cfu} / \mathrm{mL}$ in placebo and decreased from $0.7 \times 10^{6} \mathrm{cfu} / \mathrm{mL}$ to $0.2 \times 10^{6}$ $\mathrm{cfu} / \mathrm{mL}$ with levofloxacin therapy. There was a 4.9 -fold ( $95 \%$ confidence interval $[\mathrm{CI}], 1.4-25.7 ; P=0.02)$ difference in the change in bacterial load between groups. There was no effect of levofloxacin at any point on any markers of neutrophilic airway inflammation (Table 2). By day 7 there was a $1.3 \%$ reduction ( $95 \% \mathrm{CI},-11.7 \%$ to $14.3 \%)$ in percentage neutrophil count with placebo and a $12 \%$ reduction $(95 \% \mathrm{CI}$, $-5.9 \%$ to $30.1 \%$ ) in percentage neutrophil count with levofloxacin (mean difference, $10.8 \%$; $95 \% \mathrm{CI},-9.7 \%$ to $31.2 \%$; $P=0.29$ ). In patients with a baseline bacterial load higher than $\times 10^{6} \mathrm{cfu} / \mathrm{mL}$, levofloxacin treatment was associated with a greater reduction in the percentage neutrophil count compared with placebo (mean difference, 26.5\%; 95\% CI, $1.8 \%-51.3 \% ; P=0.04$; Figure 3 ) and a $46.8 \mathrm{ng} / \mathrm{mL}(95 \% \mathrm{CI}$, -11.2 to $104.8 \mathrm{ng} / \mathrm{mL} ; P=0.11)$ reduction in sputum IL-8 concentration. There was no evidence of a treatment effect at any other time (Table 2). When sputum culture at baseline revealed the presence of a PPM, the reduction in percentage neutrophil count after levofloxacin at day 7 was $45.0 \%$ compared with $2.6 \%$ when there was nonsignificant growth (mean difference, $42.3 \%$; 95\% CI, 15.5\%-69.0\%; $P=0.006$ ).

There was a significant correlation between change in percentage neutrophil count and baseline bacterial load after levofloxacin treatment ( $r=-0.78 ; P=0.003)$ and between change in percentage neutrophil count and change in bacterial load $(r=0.85 ; P=0.001)$. No such relationships were seen

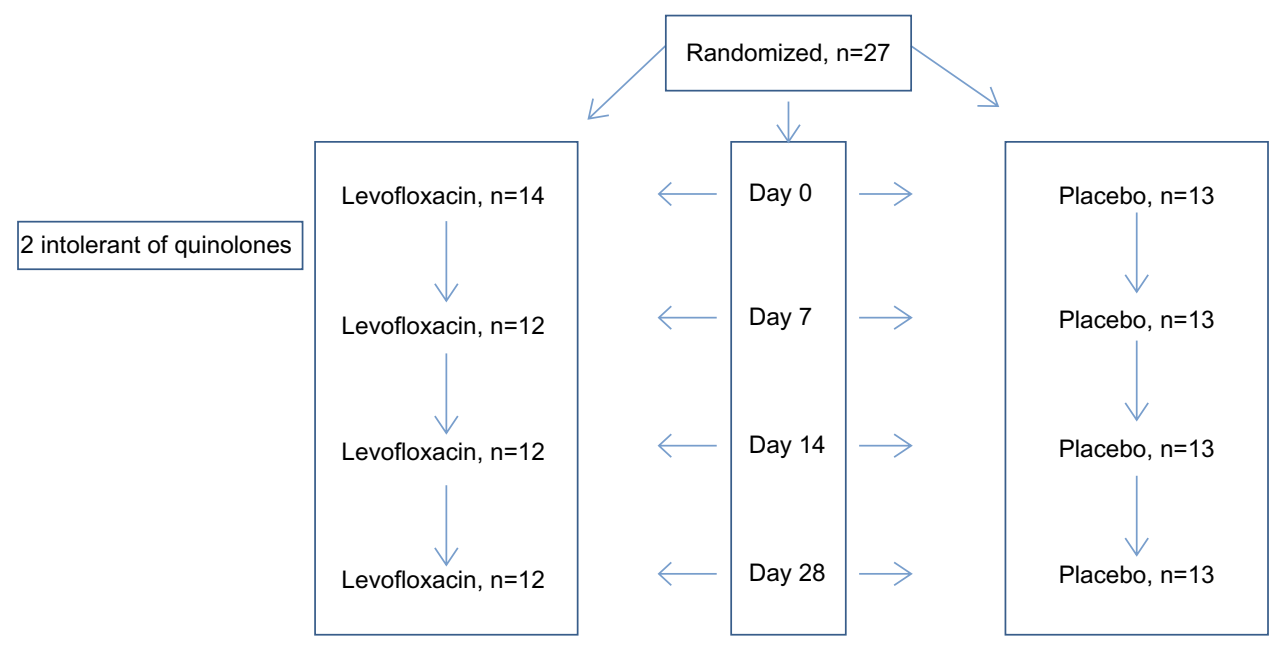

Figure I Assessments at each visit: pre- and postbronchodilator spirometry, sputum induction, and symptoms. 
Table I Patient demographics at baseline

\begin{tabular}{|c|c|c|c|}
\hline & Placebo $(n=13)$ & Levofloxacin $(n=\mid 4)$ & $P$-value \\
\hline Age (range) & $68(45-80)$ & $65(52-74)$ & 0.29 \\
\hline Sex, males & 13 & 10 & 0.10 \\
\hline Smoking status (current:ex) & $3: 10$ & $7: 7$ & 0.24 \\
\hline Smoking pack years & $49.0(29.7)$ & $49.0(29.0)$ & 1.00 \\
\hline Proportion receiving inhaled corticosteroids & $75 \%$ & $85 \%$ & 0.97 \\
\hline Inhaled corticosteroid dosage, $\mu^{\dagger}{ }^{\dagger}$ & $1,600(800-2,000)$ & $1,600(800-2,000)$ & 0.71 \\
\hline $\mathrm{FEV}_{1} / \mathrm{L}$ & $1.2(0.4)$ & $1.2(0.4)$ & 1.00 \\
\hline $\mathrm{FVC/L}$ & $2.5(0.6)$ & $2.3(0.6)$ & 0.40 \\
\hline Postbronchodilator $\mathrm{FEV}_{\mathrm{I}} / \mathrm{L}$ & I.3 (0.4) & $1.3(0.4)$ & 1.00 \\
\hline Postbronchodilator \% predicted FEV, & $43.8(13.7)$ & $48.0(16.6)$ & 0.48 \\
\hline Total lung capacity (\% predicted) & $98.0(18.7)$ & $97.7(15.1)$ & 0.96 \\
\hline Residual volume (\% predicted) & $126.9(60.4)$ & | 33.8 (45.7) & 0.74 \\
\hline $\begin{array}{l}\text { Diffusion capacity corrected for alveolar } \\
\text { volume, (\% predicted) }\end{array}$ & $66.0(26.5)$ & $74.1(18.6)$ & 0.36 \\
\hline Body mass index, $\mathrm{kg} / \mathrm{m}^{2}$ & $25.7(4.3)$ & $24.4(3.5)$ & 0.40 \\
\hline Sputum total cell count $\left(\times 10^{6} / g\right)$ & $2.62(1.8)$ & $3.8(2.3)$ & 0.15 \\
\hline Sputum neutrophil count (\%) & $66.2(19.8)$ & $70.4(21.4)$ & 0.60 \\
\hline Airway bacterial load $\left(\times 10^{6} \mathrm{cfu} / \mathrm{mL}^{*}\right)$ & I.I (0.8) & $0.7(0.9)$ & 0.24 \\
\hline $\begin{array}{l}\text { Proportion with airway bacterial load }>\times 10^{6} \\
\text { colonies, } \mathrm{n}(\%)\end{array}$ & $6(46 \%)$ & $6(43 \%)$ & 1.00 \\
\hline
\end{tabular}

Notes: Mean (standard deviation) unless stated. *Geometric mean and log standard deviation; tbeclomethasone dipropionate equivalent. Abbreviations: $\mathrm{FEV}_{1}$, forced expiratory volume in I second; FVC, forced vital capacity.

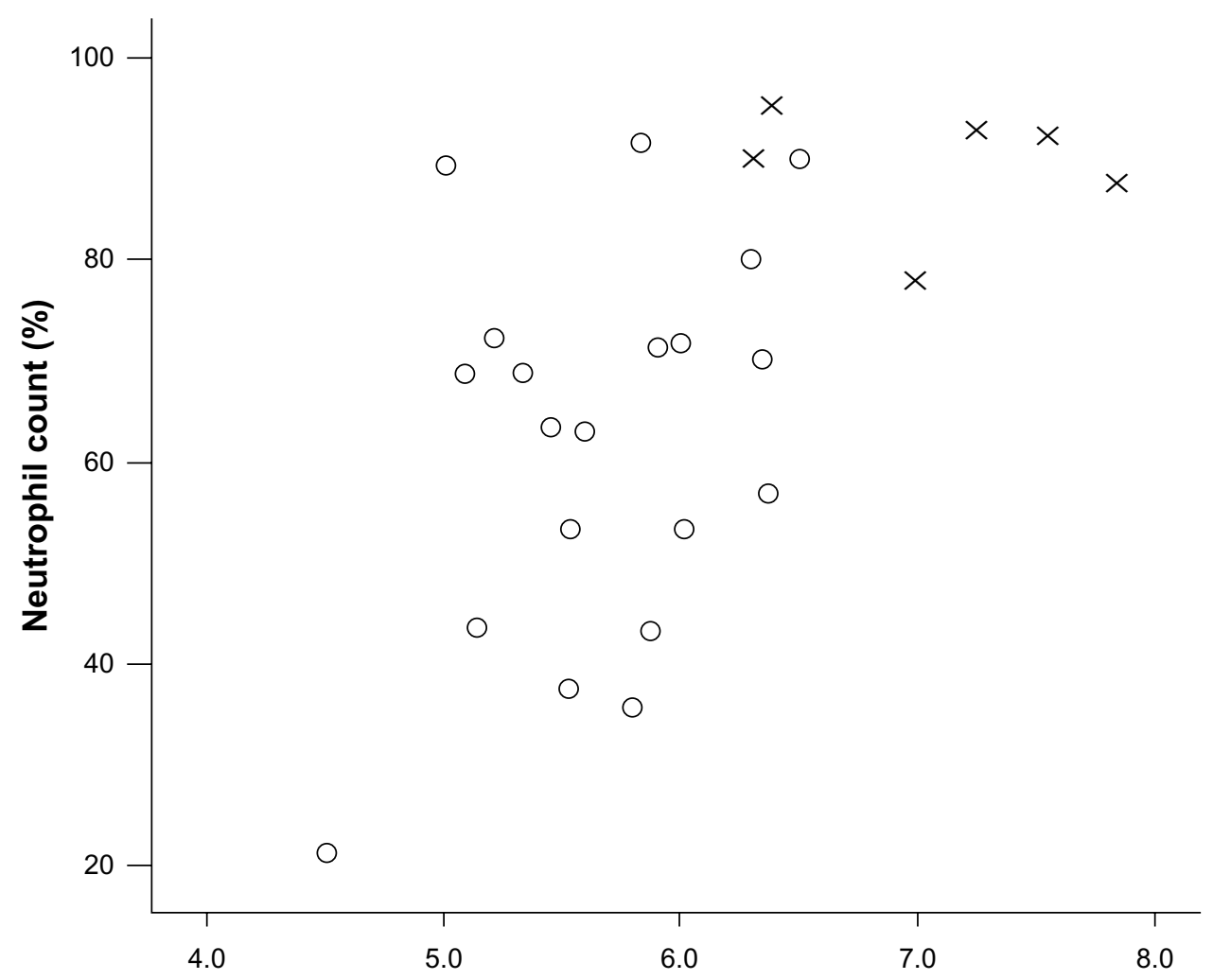

Log bacterial load (cfu/mL-1)

Figure 2 Relationship between airway bacterial load and percentage neutrophil count at baseline. Notes: $r=0.56 ; P=0.003$.

Abbreviations: $O$, nonsignificant growth; $X$, potentially pathogenic microorganisms. 
Table 2 Airway inflammation in levofloxacin and placebo groups over time series

\begin{tabular}{|c|c|c|c|c|}
\hline Treatment & Baseline & Day 7 & Day I4 & Day 28 \\
\hline \multicolumn{5}{|c|}{ Total sputum cell count $\left(\times 10^{6} / \mathrm{g}\right)$} \\
\hline Placebo & $2.1(1.3-3.2)$ & $1.6(0.9-3.0)$ & $1.7(1.0-3.1)$ & $2.4(1.5-3.8)$ \\
\hline Levofloxacin & $3.0(1.8-4.8)$ & $2.1(1.1-3.9)$ & $2.2(0.9-5.5)$ & $3.0(1.7-5.2)$ \\
\hline \multicolumn{5}{|c|}{ Neutrophil count (\%)* } \\
\hline Placebo & $66.2(19.8)$ & $64.9(17.7)$ & $58.7(20.9)$ & $59.1(19.4)$ \\
\hline Levofloxacin & $70.4(21.4)$ & $58.2(16.7)$ & $68.9(16.4)$ & $70.1(15.6)$ \\
\hline \multicolumn{5}{|c|}{ Total neutrophil count $\left(\times 10^{6} / g\right)$} \\
\hline Placebo & $1.3(0.8-2.2)$ & $1.0(0.5-2.1)$ & $1.0(0.5-1.9)$ & I.3 (0.7-2.4) \\
\hline Levofloxacin & $2.1(I . I-4.0)$ & $1.0(0.4-2.6)$ & $1.3(0.4-3.8)$ & $1.7(0.9-3.1)$ \\
\hline \multicolumn{5}{|c|}{ Interleukin-8 (ng/mL) } \\
\hline Placebo & $81.9(45.5)$ & II $3.6(82.3)$ & $120.8(62.1)$ & $95.4(75.0)$ \\
\hline Levofloxacin & $95.1(67.7)$ & $85.0(56.3)$ & I24.8 (69.7) & 91.7 (74.5) \\
\hline \multicolumn{5}{|c|}{ Log bacterial load $\left(\mathrm{cfu} / \mathrm{mL}^{-1}\right)^{\dagger}$} \\
\hline Placebo & $6.05(0.2)$ & $6.18(0.3)$ & $6.28(0.3)$ & $6.15(0.3)$ \\
\hline Levofloxacin & $5.87(0.2)$ & $5.33(0.2)$ & $5.86(0.1)$ & $5.69(0.2)$ \\
\hline
\end{tabular}

Notes: Data are presented as geometric mean ( $95 \%$ confidence interval) unless stated. *Mean (standard deviation); ${ }^{\dagger}$ geometric mean (standard deviation).

after placebo (Figure 4). There was no difference between the groups in change in postbronchodilator $\mathrm{FEV}_{1}$ (mean difference, $28 \mathrm{~mL} ; 95 \% \mathrm{CI},-70$ to $127 \mathrm{~mL} ; P=0.56$ ) or visual analog score from baseline to day 7 (mean difference, $2.6 \mathrm{~mm} ; 95 \% \mathrm{CI},-12.7$ to $17.3 \mathrm{~mm} ; P=0.71)$ or at any other time.

\section{Discussion}

We have shown a strong correlation between sputum percentage neutrophil count and baseline airway bacterial load and evidence that a reduction in bacterial load is associated with a reduction in neutrophilic airway inflammation in patients with high airway bacterial loads. This effect was only evident

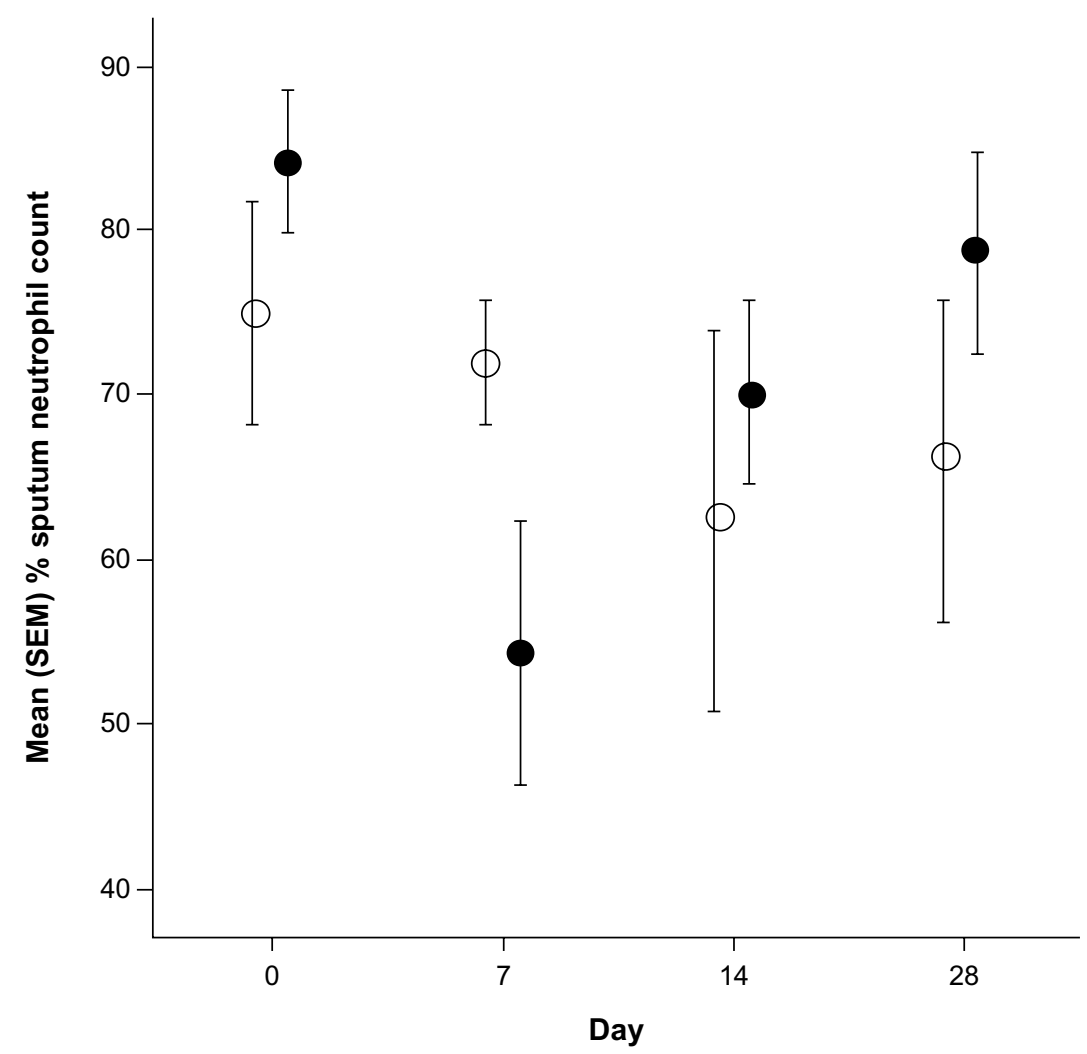

Figure 3 Change in percentage neutrophil count in patients with airway bacterial load of more than $10^{6} \mathrm{cfu} / \mathrm{mL}$.

Notes: Data presented as mean (standard error of the mean). Open circles represent placebo, closed circles represent levofloxacin.

Abbreviation: SEM, standard error of the mean. 

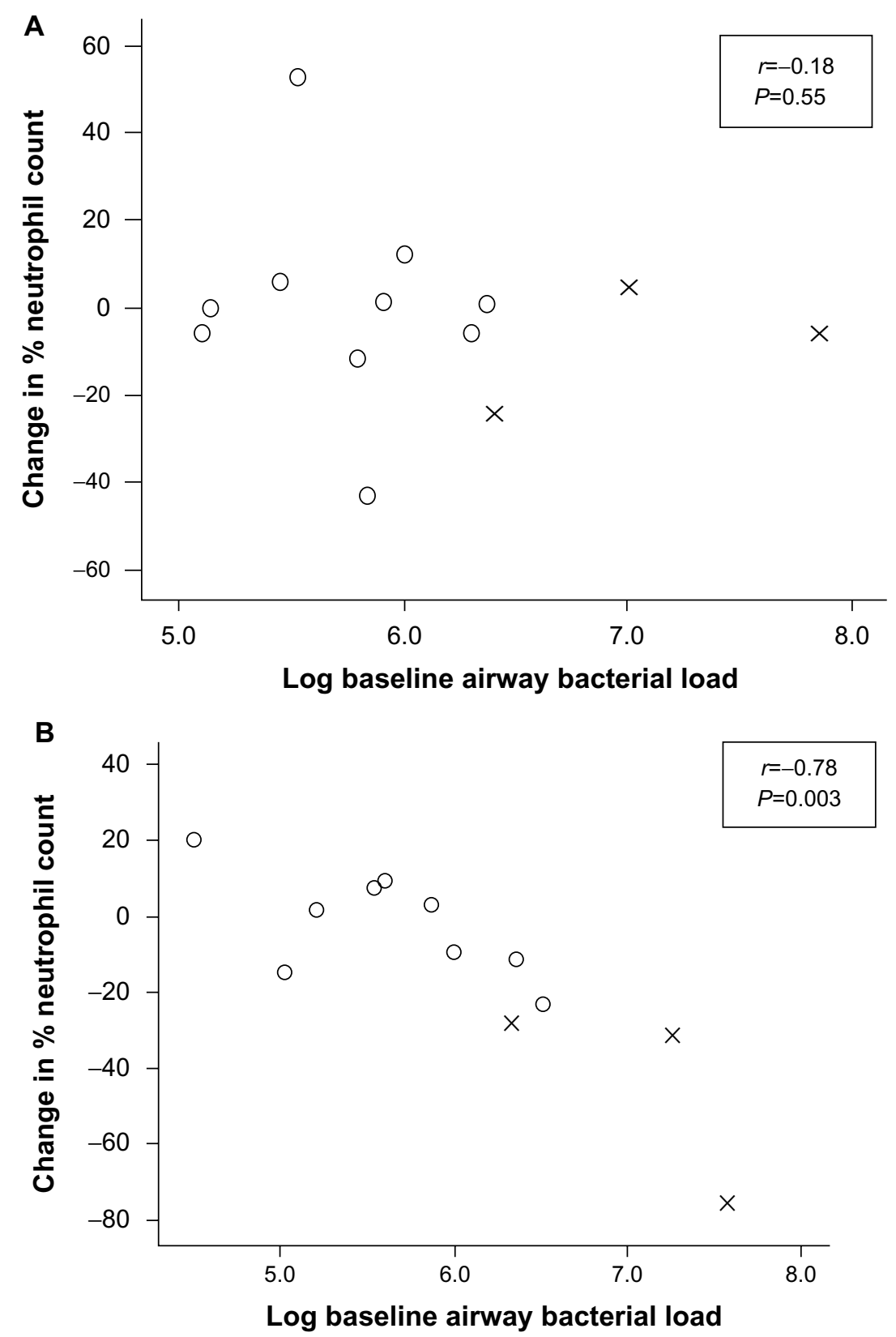

Figure 4 Mean change in percentage neutrophil count after (A) placebo and (B) levofloxacin, according to log baseline airway bacterial load. Abbreviations: $O$, nonsignificant growth; $X$, potentially pathogenic microorganism.

at day 7. There were correlations between change in percentage neutrophil count and baseline bacterial load and change in percentage neutrophil count and change in bacterial load. These effects were not associated with improvements in symptoms or $\mathrm{FEV}_{1}$.

Our findings are consistent with previous studies showing an increase in markers of neutrophilic airway inflammation associated with airway bacterial loads of more than $10^{6} \mathrm{cfu} / \mathrm{mL},,^{22,23}$ and with work showing that levels of neutrophilic airway inflammation are only suppressed for a short period after a course of antibiotics in patients with
COPD ${ }^{14}$ Our findings in stable COPD are consistent with an earlier uncontrolled trial in patients with stable bronchiectasis, in which there was evidence of reduction of neutrophil elastase concentration after treatment with amoxicillin. ${ }^{24}$ The similar time course of the effect of levofloxacin on bacterial load and sputum neutrophils and the correlation between change in sputum neutrophils and baseline bacterial load and change in bacterial load supports a causal link between airway bacterial colonization and neutrophilic airway inflammation. These findings are important, as they represent the first demonstration in a placebo-controlled trial that antibiotic 
therapy is capable of modulating neutrophilic airway inflammation in stable COPD.

We did not see any obvious clinical benefit with levofloxacin therapy during the study, although our study was not designed to show this. The long-term consequences of the effect of levofloxacin on neutrophilic airway inflammation and important clinical outcomes such as decline in lung function, quality of life, and symptoms remain unclear. However, a relationship between neutrophilic airway inflammation, decline in $\mathrm{FEV}_{1}$, and airway bacterial load is supported by a study that showed that an increase in bacterial load over the course of 12 months was related to a greater decline in $\mathrm{FEV}_{1}{ }^{4}$ Higher levels of sputum IL-8 and a change in colonizing bacterial type were also associated with a greater decline in $\mathrm{FEV}_{1}$. These findings raise the possibility that reduction of airway bacterial load and neutrophilic airway inflammation with antibiotic therapy might be associated with a reduction in disease progression, including exacerbations.

Our study was not designed to show whether the effects of levofloxacin were related to infection with a PPM. PPMs tended to be present in high concentrations, and reduction in sputum neutrophils with levofloxacin was particularly marked in these patients, raising the possibility that the effect of levofloxacin was a result of a reduction in PPMs only. However, further, larger studies are needed to investigate this.

The use of antibiotics in the treatment of exacerbations of COPD, and particularly treatment of colonized patients who are clinically stable, remains controversial. ${ }^{25,26}$ We chose to use levofloxacin because it has a broad spectrum of activity against common respiratory pathogens, it is given only once daily, it can be given to patients who are allergic to penicillin, and it is less likely to cause antibiotic resistance. ${ }^{27}$ Any potential benefits achieved by the increased use of antibiotics would have to be balanced against growing levels of bacterial antibiotic resistance and potential adverse effects, such as Achilles tendonitis and Clostridium difficile diarrhea, which may potentiate the considerable morbidity that already exists among these patients. The prophylactic use of antibiotics in COPD may be useful in a subgroup of patients ${ }^{25}$ with features of purulent sputum production or the chronic bronchitic phenotype. The mechanism by which levofloxacin may exert transitory reduction of bacterial load and neutrophil counts is not well studied. Observations from studies performed using macrolide therapy have demonstrated inhibition of neutrophil influx and stimulatory cytokine activity, ${ }^{28,29}$ but whether this is a specific immune modulatory class effect remains to be established. In our study, the most benefit occurred in patients with PPM or elevated bacterial loads. This suggests that the antibactericidal properties of levofloxacin are able to exhibit a greater effect in a subgroup with the greatest inflammatory activity. Further evidence to support this includes studies that have shown equivalence of clinical success when different antibiotics are compared after treatment of an exacerbation of COPD. ${ }^{30,31}$ Our findings provide further basis for trials investigating the effect of long-term antibiotic therapy on clinically relevant outcomes in a select group of patients with stable COPD.

\section{Acknowledgments}

We thank all the volunteers for taking part in the study and the following individuals for patient characterization; Mrs B Hargadon, Mrs S McKenna, Mrs M Shelley, and Mr S Winpress.

\section{Disclosure}

CEB and IDP have received grant support from AstraZeneca, Roche, and GlaxoSmithKline. The authors have no other conflicts of interest in this work.

\section{References}

1. Rabe KF, Hurd S, Anzueto A, et al; Global Initiative for Chronic Obstructive Lung Disease. Global strategy for the diagnosis, management, and prevention of chronic obstructive pulmonary disease: GOLD executive summary. Am J Respir Crit Care Med. 2007;176(6):532-555.

2. Fletcher C, Peto R. The natural history of chronic airflow obstruction. Br Med J. 1977;1(6077):1645-1648.

3. Donaldson GC, Seemungal TA, Patel IS, et al. Airway and systemic inflammation and decline in lung function in patients with COPD. Chest. 2005;128(4):1995-2004.

4. Wilkinson TM, Patel IS, Wilks M, Donaldson GC, Wedzicha JA. Airway bacterial load and $\mathrm{FEV}_{1}$ decline in patients with chronic obstructive pulmonary disease. Am J Respir Crit Care Med. 2003; 167(8):1090-1095.

5. O'Donnell RA, Peebles C, Ward JA, et al. Relationship between peripheral airway dysfunction, airway obstruction, and neutrophilic inflammation in COPD. Thorax. 2004;59(10):837-842.

6. Kanazawa H, Hirata K, Yoshikawa J. Accelerated decline of lung function in COPD patients with chronic hepatitis $\mathrm{C}$ virus infection: a preliminary study based on small numbers of patients. Chest. 2003;123(2): 596-599.

7. Stănescu D, Sanna A, Veriter C, et al. Airways obstruction, chronic expectoration, and rapid decline of $\mathrm{FEV}_{1}$ in smokers are associated with increased levels of sputum neutrophils. Thorax. 1996;51(3):267-271.

8. Turato G, Zuin R, Miniati M, et al. Airway inflammation in severe chronic obstructive pulmonary disease: relationship with lung function and radiologic emphysema. Am J Respir Crit Care Med. 2002;166(1): $105-110$.

9. Hogg JC, Chu F, Utokaparch S, et al. The nature of small-airway obstruction in chronic obstructive pulmonary disease. $N$ Engl $J$ Med. 2004;350(26):2645-2653.

10. Banerjee D, Khair OA, Honeybourne D. Impact of sputum bacteria on airway inflammation and health status in clinical stable COPD. Eur Respir J. 2004;23(5):685-691.

11. Bafadhel M, McKenna S, Terry S, et al. Acute exacerbations of chronic obstructive pulmonary disease: identification of biologic clusters and their biomarkers. Am J Respir Crit Care Med. 2011;184(6): $662-671$. 
12. Patel IS, Seemungal TA, Wilks M, Lloyd-Owen SJ, Donaldson GC, Wedzicha JA. Relationship between bacterial colonisation and the frequency, character, and severity of COPD exacerbations. Thorax. 2002;57(9):759-764.

13. PapiA, Bellettato CM, Braccioni F, etal. Infections and airway inflammation in chronic obstructive pulmonary disease severe exacerbations. Am J Respir Crit Care Med. 2006;173(10):1114-1121.

14. White AJ, Gompertz S, Bayley DL, et al. Resolution of bronchial inflammation is related to bacterial eradication following treatment of exacerbations of chronic bronchitis. Thorax. 2003;58(8):680-685.

15. Hill AT, Campbell EJ, Hill SL, Bayley DL, Stockley RA. Association between airway bacterial load and markers of airway inflammation in patients with stable chronic bronchitis. Am J Med. 2000;109(4): 288-295.

16. Marin A, Monsó E, Garcia-Nuñez M, et al. Variability and effects of bronchial colonisation in patients with moderate COPD. Eur Respir J. 2010;35(2):295-302.

17. Pavord ID, Sterk PJ, Hargreave FE, et al. Clinical applications of assessment of airway inflammation using induced sputum. Eur Respir J Suppl. 2002;37:40s-43s.

18. Pizzichini E, Pizzichini MM, Efthimiadis A, et al. Indices of airway inflammation in induced sputum: reproducibility and validity of cell and fluid-phase measurements. Am J Respir Crit Care Med. 1996; 154(2 Pt 1):308-317.

19. Brightling CE, Monterio W, Green RH, et al. Induced sputum and other outcome measures in chronic obstructive pulmonary disease: safety and repeatability. Respir Med. 2001;95(12):999-1002.

20. Health Protection Agency. Investigation of bronchoalveolar lavage, sputum and associated specimens. National Standard Method BSOP 57 Issue 2.3 || Available from: http//www.hpa.org.uk/webc/HPAwebFile/ HPAweb_C/1317132860548. Accessed on November 12, 2013.

21. Pye A, Stockley RA, Hill SL. Simple method for quantifying viable bacterial numbers in sputum. J Clin Pathol. 1995;48(8):719-724.
22. Stockley RA, O'Brien C, Pye A, Hill SL. Relationship of sputum color to nature and outpatient management of acute exacerbations of COPD. Chest. 2000;117(6):1638-1645.

23. Stockley RA, Hill AT, Hill SL, Campbell EJ. Bronchial inflammation: its relationship to colonizing microbial load and alpha(1)-antitrypsin deficiency. Chest. 2000;117(5 Suppl 1):291S-293S.

24. Stockley RA, Hill SL, Morrison HM. Effect of antibiotic treatment on sputum elastase in bronchiectatic outpatients in a stable clinical state. Thorax. 1984;39(6):414-419.

25. Sethi S, Jones PW, Theron MS, et al; PULSE Study group. Pulsed moxifloxacin for the prevention of exacerbations of chronic obstructive pulmonary disease: a randomized controlled trial. Respir Res. 2010;11:10.

26. Albert RK, Connett J, Bailey WC, et al; COPD Clinical Research Network. Azithromycin for prevention of exacerbations of COPD. N Engl J Med. 2011;365(8):689-698.

27. Lode $\mathrm{H}$, Allewelt M. Role of newer fluoroquinolones in lower respiratory tract infections. J Antimicrob Chemother. 2002;49(5):709-712.

28. Takizawa H, Desaki M, Ohtoshi T, et al. Erythromycin modulates IL-8 expression in normal and inflamed human bronchial epithelial cells. $\mathrm{Am}$ J Respir Crit Care Med. 1997;156(1):266-271.

29. Kadir T, Izzetin FV, Cevikbaş A, Johansson CB, Clark P. In vitro effects of clarithromycin on human polymorphonuclear leukocyte functions. Chemotherapy. 2000;46(3):198-203.

30. Wilson R, Allegra L, Huchon G, et al; MOSAIC Study Group. Shortterm and long-term outcomes of moxifloxacin compared to standard antibiotic treatment in acute exacerbations of chronic bronchitis. Chest. 2004;125(3):953-964.

31. Wilson R, Anzueto A, Miravitlles M, et al. Moxifloxacin versus amoxicillin/clavulanic acid in outpatient acute exacerbations of COPD: MAESTRAL results. Eur Respir J. 2012;40(1):17-27.
International Journal of COPD

\section{Publish your work in this journal}

The International Journal of COPD is an international, peer-reviewed journal of therapeutics and pharmacology focusing on concise rapid reporting of clinical studies and reviews in COPD. Special focus is given to the pathophysiological processes underlying the disease, intervention programs, patient focused education, and self management protocols.

\section{Dovepress}

This journal is indexed on PubMed Central, MedLine and CAS. The manuscript management system is completely online and includes a very quick and fair peer-review system, which is all easy to use. Visit http://www.dovepress.com/testimonials.php to read real quotes from published authors. 